\title{
Provas de nomeação e imitação como instrumentos de diagnóstico do transtorno fonológico***
}

\author{
Picture naming and imitation tests as tools for the diagnosis of \\ phonological disorder
}

\author{
Haydée Fiszbein Wertzner* \\ Ana Carolina Camargo Salvatti Papp** \\ Daniela Evaristo dos Santos Galea**
}

*Fonoaudióloga. Livre-Docente. Professora Associada do Curso de Fonoaudiologia do Departamento de Fisioterapia, Fonoaudiologia e Terapia Ocupacional, da Faculdade de Medicina da Universidade de São Paulo. Endereço para correspondência: R. Cipotânea, 51 - São Paulo - SP CEP 05360-160 (hfwertzn@usp.br).

**Fonoaudióloga. Doutoranda em Semiótica e Lingüística Geral pela Faculdade de Filosofia, Letras e Ciências Humanas da Universidade de São Paulo.

****Trabalho Realizado na Universidade de São Paulo.

Artigo de Pesquisa

Artigo Submetido a Avaliação por Pares

Conflito de Interesse: não

Recebido em 19.07.2005. 25.04.2006.

Aceito para Publicação em 01.08.2006.
Revisado em 22.08.2005; 03.01.2006;

\begin{abstract}
Background: phonological disorder. Aim: to verify the association between the phonological performance in picture naming and imitation tasks, assessing the occurrence of phonological processes and using the severity indexes of Percentage of Correct Consonants and Phonological Density Index. Method: participants of this research were 50 phonologically disordered children, with no history of prior speech-language therapy and with ages between 4:0 and 12 years. Results: The analysis of the phonological processes indicated that the non-productive processes were more frequent than the productive ones, not only in the imitation task but also in the picture naming task. It was observed that in both tasks, most participants presented the phonological processes of cluster reduction, liquid simplification and final consonant deletion, independently of their productivity. When comparing both tasks, there was an association and agreement regarding the number of participants who presented phonological processes as well as a correlation regarding the total number of phonological processes; there was no evidence of differences concerning the averages of the phonological processes observed in the imitation and picture naming tasks; a negative correlation was observed between the severity indexes Percentage of Correct Consonants and Phonological Density Index; moreover, these values presented a strong correlation in both tests, indicating that they detect similar severity levels. Conclusion: the study verified an association and agreement between the picture naming and imitation tasks, not only for the number of participants who presented phonological processes, but also for the number of phonological processes, thus indicating the importance of using structured tests for the diagnosis of phonological disorder. Furthermore, for the severity indexes, Percentage of Correct Consonants and Phonological Density Index, a high correlation was observed between the tasks, indicating that both tasks are useful instruments in detecting phonological disorder.
\end{abstract}

Key Words: Articulation Disorders; Speech Articulation Tests; Severity of Illness Index.

\section{Resumo}

Tema: transtorno fonológico. Objetivo: verificar a associação entre o desempenho fonológico nas provas de nomeação e de imitação medido pela ocorrência dos processos fonológicos e pelos índices de gravidade Porcentagem de Consoantes Corretas e Densidade de Processos Fonológicos. Método: participaram da pesquisa 50 crianças com diagnóstico de transtorno fonológico sem terapia fonoaudiológica prévia e com idade entre 4:0 e 12 anos. Resultados: A análise dos processos fonológicos evidenciou que os não-produtivos foram registrados em maior número do que os processos produtivos tanto na prova de nomeação quanto de imitação. Observou-se que em ambas as provas, mais sujeitos apresentaram os processos simplificação do encontro consonantal, simplificação de líquidas e eliminação da consoante final, independentemente da produtividade. Na comparação das duas provas houve associação e concordância quanto ao número de sujeitos que apresentou processos fonológicos bem como correlação para o número total de processos fonológicos; não houve evidências de diferenças nas médias do total de processos fonológicos ocorridos nas provas de nomeação e imitação; observou-se correlação negativa entre os índices de gravidade Porcentagem de Consoantes Corretas e Densidade de Processos Fonológicos estudados, além de que os seus valores nas duas provas apresentaram forte correlação indicando que detectam grau de gravidade semelhante. Conclusão: verificou-se a associação e a concordância entre as provas de imitação e de nomeação, tanto para o número de sujeitos que apresentou processos fonológicos como para o número de ocorrências de processos fonológicos, evidenciando a importância de provas estruturadas para o diagnóstico do transtorno fonológico. Além disso, para os índices de gravidade Porcentagem de Consoantes Corretas e Densidade de Processos Fonológicos, observou-se alta correlação entre as provas, confirmando que ambas são instrumentos adequados para a detecção do transtorno fonológico.

Palavras-Chave: Transtornos da Articulação; Testes de Articulação da Fala; Índice de Gravidade de Doença.

Referenciar este material como:

WERTZNER, H. F. ; PAPP, A. C. C. S. ; GALEA, D. E. S. Picture naming and imitation tests as tools for the diagnosis of phonological disorder (original title: Provas 3 de nomeação e imitação como instrumentos de diagnóstico do transtorno fonológico). Pró-Fono Revista de Atualização Científica, Barueri (SP), v. 18, n. 3, p. 303312, set.-dez. 2006. 


\section{Introduction}

The phonological disorder is defined as a speech disorder characterized by the inadequate production of sounds, as well as by the inadequate use of phonological rules of the language regarding the sound distribution and the type of syllabic structure. Its cause is unknown and there is variation in the severity degree and speech intelligibility (Wertzner, 2002).

In general, the authors who study the phonology of children with phonological disorder consider that the systems presented are mostly similar to those of children with a typical development, and in some cases there might also occur phonological processes that are not regularly observed during the development. Although there is a foresight of a certain sequence and velocity in the phonological development, it is believed that each child develops language in a particular way, and that the individual variation is very important (Ingram, 1976).

Phonological disorder may have several correlate causes. In order to classify it there is a proposal of five subtypes (Shriberg et al., 2001; Shriberg, 2002; Shriberg et al., 2003): genetic speech delay, otitis media with effusion, developmental apraxia, psychosocial involvement, and residual errors. Furthermore, other aspects are related to this disorder, such as age and gender.

It can also be stressed that children diagnosed with phonological disorder at a pre-school age may present reading and writing learning difficulties. This matter worries the speech pathologists who search to find evidence based procedures that allow a better efficiency in the diagnosis concerning the sensitivity and the specificity of the tests (Dollaghan, 2004; Plante, 2004; Law et al., 2004; Law, 2004).

For the diagnosis of the phonological disorder it is necessary to apply several tests of: oral language (comprehension and expression), reading and writing, specific tests of phonology, phonological processing, oral myofunctional system, stimulability, diadochokinetic, audiological (behavioral and electrophysiological) (Peña-Brooks \& Hedge, 2000; Khan, 2002; Wertzner, 2004; Castro, 2004).

Within the phonology tests, three types of tasks are commonly used: imitation, naming and spontaneous speech. Each of these tests has variations regarding the stimulus type, with advantages and disadvantages (Wertzner, 2003).

The spontaneous speech may be elicited direct or indirectly. In direct conditions, questions are used to evoke answers, however these questions are not used in the indirect condition. The indirect speech collecting may be done through a free situation (selected materials and topics; the topics may or may not be related to the materials) or through history (use of some selected material and topics chosen by the child); the routine is a direct way of collecting (some materials and house miniatures with all consonantal phonemes; children may or may not use these stimuli to initiate speech); the interview (when the examiner asks questions to the child) and the script (materials such as pictures from books, words and themes are chosen to evoke all consonantal sounds through questions asked by the examiner) are direct and indirect ways (Shriberg \& Kwiatkowski, 1985).

In the imitation tasks, the subject is requested to repeat a word or sentence. Among these tasks, for the English language, there is the GoldmanFristoe (1986); for the Portuguese language, there is the imitation task of the Child Language Test ABFW (Wertzner, 2000).

In the naming task it is expected that the subject say the equivalent word to the picture or object presented as stimulus. It's also usual to request the subject to produce the target word in a standard sentence (Wertzner \& Galea, 2002). In this kind of test, as the aim is to verify how the subject uses the phonological rules of the language and produces the sounds, if he/she does not recognize the picture/object, the examiner may say the respective name and request the naming again after showing some items.

It is observed that pre-school children's performance is typically better in naming and imitation tasks than in syntactically organizing more complex tasks, mainly because many factors influence directly the quantity and the quality of a child's speech (Hoffman \& Norris, 2002; Goldstein et al., 2004).

Nevertheless, other studies show that children may have a better performance in spontaneous speech tasks when compared to imitation and naming tasks, once they avoid the phonemes they cannot produce. Thus, children would present lesser use of phonological processes in the spontaneous speech compared to other types of 
evaluation (Galea, 2003).

As there is a certain degree of speech unintelligibility in the phonological disorder, many times it is impossible to understand the child's discourse jeopardizing the analysis of the phonological processes. Despite being a longer task, the spontaneous speech also depends on the child participation in the evaluation process, which might interfere in the quality of the discourse (Johnson et al., 2004). In directed tasks, such as the tasks from the Child Language Test ABFW (Wertzner, 2000), the sample collecting is easier allowing a more complete analysis of the child's phonological system and, therefore a more precise diagnosis.

The phonological disorder evaluation using the phonological processes analysis introduced by Ingram (1976) is present in several studies, such as Wertzner et al. (2001), Wertzner \& Oliveira (2002), Wertzner et al. (2002), Papp (2003).

Phonological process is defined as any systematic simplification that affects a sound class (Wertzner, 2003). In the literature there are three types of phonological processes that are more cited: the syllabic structure ones that alter the word's syllabic structure following the general tendency to reduce the word's structure to Consonant Vowel (CV); the substitution ones where there is a substitution of a sound by another from another sound class, sometimes affecting a whole class of sounds; and the assimilation ones where the sound changes becoming similar to one that comes first or after it (Ingram, 1976).

A discussed issue among the researchers of the phonological disorder is its severity. That's because it would be one of the ways to try to separate, through one or more quantitative indexes, the different subtypes of phonological disorders, as well as to better equip the therapeutic procedures. The phonological disorder severity may be manifested in different degrees providing variability in the speech intelligibility (Cumley, 2001; Keske-Soares et al., 2004; Khan, 2002; Vieira et al., 2004; Whitehead et al, 2004). Thus, the speech-language research and practice require procedures that quantify the severity and the impact of the communication disorders (Shriberg \& Kwiatkowski, 1982).

Shriberg and Kwiatkowski (1982) proposed several measures to quantify the severity of the phonological disorder, and also to help in the differentiation of the disorder's subtypes. The authors developed a procedure named Percentage of Correct Consonants (PCC) that verifies the number of correct consonants produced in a speech sample, considering the total number of consonants in this sample. They determined the values and the respective adjectives to be applied at each value band. Thus, the child was classified as having a mild phonological disorder if the PCC was from 85 to $100 \%$, mild-moderate between $65 \%$ and $85 \%$, moderate-severe between $50 \%$ and $65 \%$, and severe if the PCC was below 50\%. The authors alerted that the examiner should consider only the consonants that were surely correctly produced. The omissions, substitutions and common and uncommon distortions have the same weight, that is, all of them are considered incorrect.

In 1992, Edwards points another phonological disorder severity measure, the Process Density Index (PDI). In order to get this measure it is necessary to calculate the total number of phonological processes and divide it by the number of analyzed words in the sample. The PDI is not related to a specific type of speech sample and it can be used with any test or evaluation procedure. Although further refinements are necessary, the PDI can be seen as a measure of great clinical potential for the phonological severity and/or intelligibility.

According to what was exposed above, it is clear the importance of the classification of the phonological disorder severity and its implications for the diagnosis and intervention. The most used indexes in the literature (PCC and PDI) were designed for the English language. Unfortunately, it is not possible to transpose these indexes values as well as the errors definitions to the Portuguese language. Therefore, describing and classifying the alterations according to the Portuguese phonology, verifying the descriptors that base the severity perceptual judgment done by the Portuguese speaking speech pathologist, is the most important point for the diagnosis of the several subtypes of phonological disorder.

Some studies were accomplished for the Brazilian Portuguese aiming to assist the diagnostic process of this disorder (Pagan \& Wertzner, 2002; Wertzner et al, 2004a, b).

The evaluation of children with language and speech disorders is very important and is a critical component for the clinical process. Besides providing the diagnosis, it helps the clinician in relation to the treatment, once it enables to indicate which phonological process should be addressed first in order to obtain a faster and efficient treatment (Tyler et al., 2002).

Thus, the purpose of this research was to verify the association between the phonological 
performance in the naming and imitation tasks measured by the occurrence of phonological processes and by the severity indexes.

\section{Method}

The present research was approved by the Ethics Committee for Research Projects Analysis (Capesq) protocol no 286/99. All children's care takers signed the Informed Consent Term.

Fifty children, 15 female and 35 male, took part in this research; all of them were patients of two Speech language Services supervised by professors from the Speech Language Course of the FMUSP, the Speech Language Laboratory in Phonology (LIF) that functions in the building of the Speech and Hearing Sciences Department of FMUSP, located at the University Campus, and the Speech Language Division of the Health Center Professor Samuel Barsnley Pessoa (CSE), under the responsibility of the Medical school of the University of Sao Paulo.

The subjects' inclusion criteria were: a phonological disorder diagnosis, no previous speech-language treatment, and age between 4:0 and 12:0 years.

All subjects underwent a speech-language evaluation comprised by: anamnesis, audiological evaluation, all tasks from the Child Language Test - ABFW (Andrade et. al, 2000), oral myofunctional system's evaluation, and phonological awareness evaluation.

During the initial interview with the parents or care takers, the Informed Consent Term was signed, authorizing the child's participation in the research.

After the diagnosis, the protocols of the phonology tasks from the ABFW were analyzed according to the description proposed in the test. These tasks were video and audio recorded. Thus, during the tasks application the examiner sat in front of the subject and the material and the registration sheets were on the table. The tape recorder was positioned with the microphone directed to the child avoiding interferences and allowing a better phonetic transcription of the tasks. The video recorder was placed on a tripod, favoring the observation of the articulatory production and minimizing the possibility of difficulties in the phonetic transcription.

The following phonological processes were analyzed (Chart 1)
The phonological processes were analyzed according to their occurrence. Thus, those with more than $25 \%$ of occurrence in each task were called productive (PFP) and those with less than $25 \%$ of occurrence were called non-productive (PFNP).

CHART 1. Phonological processes analyzed.

\begin{tabular}{|c|c|}
\hline Phonological Processes & EXAMPLE \\
\hline Syllable reduction (RS) & 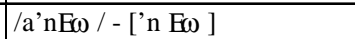 \\
\hline Consonantal harmony (HC) & /sa’patu/ - [pa’patu] \\
\hline Fricative plosivation (PF) & /'faka/ - [’paka] \\
\hline Backing to velar (PV) & /'pRatu/ - [’pRaku] \\
\hline Backing to palatal (PP) & /va’sora/ - [va’'Eora] \\
\hline Palatal fronting (FP) & $/$ xe'l $\quad \mathrm{Zu} /$ - [xe'l $\quad \mathrm{zu}]$ \\
\hline Velar fronting (FV) & /‘kãma/ - [tãma] \\
\hline Liquid simplification (SL) & /ka'dera/ - [ka'dela] \\
\hline Consonantal cluster simplification (SEC) & /‘bLuza/ - [’bRuza] ou ['buza] \\
\hline Final consonant simplification (SCF) & /'paSta/ - [’pata] \\
\hline Plosive voicing (SP) & /‘pRatu/ - [bRatu] \\
\hline Fricative voicing (SF) & $/ \mathrm{pa}^{\prime} \times$ asu/ $-[\mathrm{pa} \times$ azu] \\
\hline Plosive devoicing (EP) & /‘dedu/ - [’tetu] \\
\hline Fricative devoicing (EF) & /‘meza/ - [’mesa] \\
\hline
\end{tabular}

\section{Results}

Examining the total occurrence of phonological processes, it's observed that the non-productive ones were more frequent than the productive ones (Table 1).

Figure1 shows the number of phonological processes presented by the subjects in both tasks, in a productive and non-productive way and the total. Concerning the total number of processes there seems to be a difference between the tasks. It is observed the presence of outliers either for the number of productive and non-productive processes as for the total, and these subjects used more phonological processes than the group average. It can be observed a minor variability of data in the productive processes in the imitation task.

Table 2 shows the percentage of subjects who presented productive phonological processes in the imitation and naming tasks respectively. It's observed that in both tasks more subjects presented productively the processes SEC, SL ECF. It's interesting too observe that of the 14 
phonological processes analyzed; only tem were productive in the imitation task and nine in the naming task. It's also observed that independently of the productivity, the most used processes by the subjects were SEC, SL, ECF.

In order to verify the association between the total number of subjects who presented each phonological process in both tasks, the Exact Test of Fisher was used (significance level 0,05). There were evidences that, except from the phonological processes of fricative voicing, syllable reduction and consonantal harmony, there was an association for the other ones (TABLE 3).

For the 11 phonological processes that the Fisher test pointed the existence of association, the Kappa coefficient was calculated in order to analyze the concordance between the use of each process in each task. It can be verified also in TABLE 3 that there is a concordance between the occurrence of phonological processes in both tasks.

Considering only the phonological processes with productive occurrence, Table 4 shows that the Fisher test was significant for the nine productive processes in the studied subjects. In order to complement the Fisher test, the statistics Kappa was applied for all productive phonological processes indicating that there is a concordance for all of them.

For the non-productive phonological processes, the Fisher test was significant only for the process of liquid simplification indicating that only when this process was used in a nonproductive way in a task, it was also used the same way in the other task. The Kappa test indicates concordance for this process in both tasks (TABLE 5).

Another analysis performed concerns the total number of phonological processes presented in the imitation and in the naming tasks. Two studies were carried out; the first one was an average comparison by the paired t-test which obtained a $\mathrm{p}=0,117$ (significance level 0,05 ), not showing evidences of differences in the averages of the total phonological processes used in both tasks.

The Spearman correlation was $0,661(p=0,000)$ evidencing a correlation between the total number of phonological processes used in the naming and in the imitation.

The same analysis was done considering only the number of productive phonological processes in the imitation and in the naming tasks. The paired t-test pointed a $\mathrm{p}=0,040$ indicating that there was a difference between the averages of productive phonological processes observed in the imitation and in the naming tasks. The Spearman correlation was $0,824(p=0,000)$ showing a correlation between the number of productive processes used in both tasks.

In the study of the non-productive phonological processes, the paired t-test pointed $\mathrm{a}=0,027$ indicating that there was a difference between the averages of non-productive phonological processes in the imitation and naming tasks. The Spearman correlation was 0,463 ( $p=0,001$ ) showing a correlation between the number of non-productive processes used in both tasks.

Considering that the indexes obtained by the 50 subjects in the PCC and in the PDI in the imitation and naming tasks, it was verified that the Spearman correlation between the all the indexes (TABLE 6). However, the correlation between the PCC and the PDI is negative indicating that when one increases the other decreases. Considering these two severity indexes it can be verified that the two tests detect the same alterations, not existing a difference between them.

Another analysis performed for the comparison of the indexes was the paired t-test which compared the PCC and the PDI averages in both tasks. For the PCC, the paired t-test indicated a $\mathrm{p}=0,378$ and for the PDI, $p=0,763$ (significance level 0,05) pointing out that there are no evidences of difference between the averages of the indexes in both tasks.

TABLE 1. Occurrence of phonological processes.

\begin{tabular}{|c|c|c|c|}
\hline & Productive & Non- Productive & Total \\
\hline Naming & 78 & 110 & 188 \\
\hline Imitation & 90 & 96 & 186 \\
\hline Total & 168 & 206 & 374 \\
\hline
\end{tabular}


FIGURE 1. Number of phonological processes observed in the subjects.

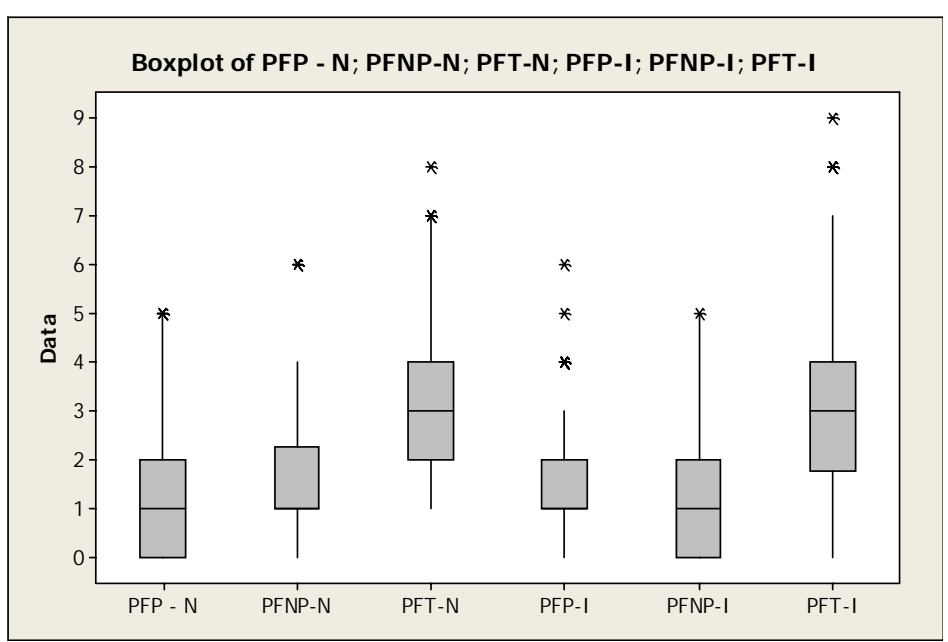

Legend: PFP - I: productive phonological process in the imitation task; PFP $\mathrm{N}$ : productive phonological process in the naming task; PFNP- I: non-productive phonological process in the imitation task; PFNP-N: non-productive phonological process in the naming task; PFT- I: phonological process in the total of the imitation task; PFT - N: phonological process in the total of the naming task.

TABLE 2: Percentage of subjects who presented phonological processes (productive and independently of the productivity) in both tasks.

\begin{tabular}{ccccc}
\hline & PFP - I & PFP - N & PFIP - I & PFIP - N \\
\hline SEC & 72 & 50 & 89 & 83 \\
SL & 38 & 30 & 58 & 64 \\
ECF & 33 & 33 & 39 & 44 \\
FP & 26 & 20 & 28 & 28 \\
EF & 20 & 22 & 36 & 48 \\
EP & 18 & 20 & 32 & 34 \\
PF & 8 & 8 & 10 & 34 \\
FV & 8 & 8 & 18 & 16 \\
PP & 7 & 7 & 22 & 9 \\
PV & 2 & 0 & 10 & 8 \\
SP & 0 & 0 & 12 & 4 \\
SF & 0 & 0 & 2 & 8 \\
RS & 0 & 0 & 4 & 18 \\
HC & 0 & 0 & 10 & 4 \\
\hline & & & & \\
\hline
\end{tabular}


TABLE 3. Association between the number of subjects who presented phonological processes in the naming and imitation tasks.

\begin{tabular}{ccc}
\hline & Fisher Exact Test (P) & Kappa \\
\hline ECF & 0,000 & 0,765 \\
SP & 0,012 & 0,468 \\
SF & 1,000 & -------- \\
EP & 0,000 & 0,593 \\
EF & 0,000 & 0,515 \\
RS & 0,331 & ------ \\
PF & 0,003 & 0,355 \\
HC & 0,192 & ------ \\
FV & 0,003 & 0,504 \\
FP & 0,000 & 0,792 \\
SEC & 0,000 & 0,860 \\
SL & 0,000 & 0,623 \\
PV & 0,045 & 0,390 \\
PP & 0,001 & 0,516
\end{tabular}

TABLE 4. Association between the number of subjects who used phonological processes in the naming and imitation tasks.

\begin{tabular}{|c|c|c|}
\hline Phonological Processes & Fisher Exact Test (P) & Kappa \\
\hline ECF & 0,000 & 0,811 \\
\hline SP & --- & --- \\
\hline SF & --- & 0,805 \\
\hline EP & 0,000 & 0,819 \\
\hline EF & 0,000 & --- \\
\hline RS & --- & --- \\
\hline EE & --- & 1,000 \\
\hline PF & 0,000 & --- \\
\hline HC & --- & 0,728 \\
\hline FV & 0,001 & 0,820 \\
\hline FP & 0,000 & 0,423 \\
\hline SEC & 0,006 & 0,646 \\
\hline SL & 0,000 & --- \\
\hline PV & --- & 1,000 \\
\hline PP & 0,000 & \\
\hline
\end{tabular}

Legend the Tabelas 2, 3, 4, 5 e 6: ECF: final consonant elimination; SP: plosive voicing; SF: fricative voicing; EP: plosive devoicing; EF: fricative devoicing; RS: syllable reduction; EE: stridency elimination; PF: fricative plosivation; HC: consonantal harmony; FV: velar fronting; FP: palatal fronting; SEC: consonantal cluster simplification; SL: liquid simplification; PV: velar plosivation; PP: backing to palatal. 
TABLE 5: Association between the number of subjects who used non-productive phonological processes in the naming and imitation tasks

\begin{tabular}{|c|c|c|}
\hline Phonological Processes & Fisher Exact Test (P) & Kappa \\
\hline ECF & 0,079 & ---- \\
\hline SP & 0,120 & --- \\
\hline SF & 1,000 & --- \\
\hline EP & 0,071 & ---- \\
\hline EF & 0,413 & --- \\
\hline RS & 0,331 & --- \\
\hline EE & 1,000 & ---- \\
\hline PF & 0,260 & ---- \\
\hline HC & 0,192 & ---- \\
\hline FV & 0,423 & --- \\
\hline FP & 0,080 & 0,356 \\
\hline SEC & 1,000 & ---- \\
\hline SL & 0,021 & --- \\
\hline PV & 0,226 & \\
\hline PP & 0,140 & \\
\hline
\end{tabular}

TABLE 6. Spearman Correlation for the PCC and PDI indexes in the imitation and in the naming.

\begin{tabular}{|c|c|c|c|c|c|}
\hline & & PCC imitation & PCC naming & PDI imitation & PDI naming \\
\hline \multirow{2}{*}{ PCC imitation } & Correlation coefficient & 1,000 & 0,881 & $-0,969$ & $-0,882$ \\
\hline & $\mathrm{P}$ & & 0,000 & 0,000 & 0,000 \\
\hline \multirow{2}{*}{ PCC naming } & Correlation coefficient & 0,881 & 1,000 & $-0,9$ & $-0,992$ \\
\hline & $\mathrm{P}$ & 0,000 & & 0,000 & 0,000 \\
\hline \multirow{2}{*}{ PDI imitation } & Correlation coefficient & $-0,969$ & $-0,9$ & 0,901 & 1 \\
\hline & $\mathrm{P}$ & 0,000 & 0,000 & & 0,000 \\
\hline \multirow{2}{*}{ PDI naming } & Correlation coefficient & $-0,882$ & $-0,992$ & 0,901 & 1 \\
\hline & $\mathrm{P}$ & 0,000 & 0,000 & 0,000 & \\
\hline
\end{tabular}

\section{Discussion}

As pointed by Ingram (1976) a differentiation between production difficulties and phonological rules comprehension may be identified when comparing the phonological performance in the naming and imitation tasks. The results found in this study show that the productive phonological processes, that is, those that had an occurrence above $25 \%$, were mostly found in the imitation task while the non-productive phonological processes were more frequent in the naming task.

Thus, the studied subjects presented greater difficulty in understanding and/or using the phonological rules of the Brazilian Portuguese, since sometimes the sound is produced correctly and sometimes it is not.
Some researches for the English language suggest that the majority of children with phonological disorder do not have difficulty in producing sounds (Shriberg, 1999; Shriberg et al., 2001; Shriberg, 2002; Castro, 2004). Many times, children present articulatory imprecision or even absence of a certain sound production, which occurs more frequently in the liquid phonemes (Castro, 2004).

The average comparison of the PCC and PDI indexes obtained in the imitation and in the naming tasks shows that both tasks detect the same alterations, not existing differences between them. It was also found a correlation between these two indexes in both tasks confirming that they can be 
used to classify the severity of the phonological disorder similarly (Wertzner et al., 2001; Wertzner, 2002; Wertzner et al., 2004b).

The high correlation between the PCC found in the imitation and in the naming tasks, as well as for the PDI, indicates that both tasks from the ABFW phonology test (Wertzner, 2000) are well dimensioned for the phonological disorder diagnosis.

The phonological analysis of the phonological processes in the imitation and naming tasks (Wertzner, 2000) demonstrated association and concordance between both tasks regarding the number of subjects who used phonological processes, either for the total as for the ones used productively. This points out that for the majority of the phonological processes there is an association between the number of subjects who used them in the imitation and naming tasks, indicating that if a subject used one of these processes in one task, he/she will tend to use it in the other one. The same was not verified for the non-productive phonological processes where there was an association only for the phonological process of liquid simplification. This may indicate that the subjects who use non-productive phonological processes have greater instability in the phonological system which indicates that the use of a non-productive phonological process in one task is not repeated in the other task. This fact may point to a difficulty in the motor programming of the sounds leading to unconscious errors (Crosbie et al, 2005).

The comparison of the averages of phonological processes occurred in each task imitation and naming - evidences that there were no statistical differences between the two tasks. There was also a correlation between the total number of phonological processes used in both tasks. Analyzing the productive and the nonproductive phonological processes separately, there were differences between the averages in both tasks indicating a higher occurrence of productive processes in the naming task and of nonproductive in the imitation task. This data show that although the average of productive and nonproductive phonological processes use in both tasks is different, when the occurrence of these processes increase in one task it also increases in the other task.

Therefore, the speech-language evaluation with emphasis in the phonology implicates the necessity of the children's speech sample in different types of phonological tasks (Ingram, 1976; Tyler et al, 2002). This is a very important factor for the diagnosis of the phonological disorder, since each task privileges one aspect, that is, the sound production considering also its motor programming and the phonological organization (Betz \& StoelGamon, 2005; Crosbie et al, 2005, Shriberg et al, 1985).

Considering the necessity of precise instruments for the phonological disorder diagnosis, the present study evidences that either the imitation as the naming task may be used once both severity indexes and the occurrence of phonological processes were similar. It can also be said that these tasks provide important elements for the intervention model that will be applied with each subject.

\section{Conclusion}

This study allowed verifying the association and the concordance between the imitation and the naming tasks either for the number of subjects who presented phonological processes, as for the number of occurrences of phonological processes evidencing the importance of structured tasks for the phonological disorder diagnosis.

Furthermore, the PCC and the PDI indexes had a high correlation between the tasks, confirming that the imitation and the naming are adequate tools for the detection of the phonological disorder severity degree.

Acknowledgments to: Fapesp Process 00/09220-3; Process 00/00197-9; Process 99/08058-9. 


\section{References}

ANDRADE, C. R. F.; BÉFI-LOPES, D. M.; FERNANDES, F. D. M.; WERTZNER, W. H. ABFW: Teste de linguagem infantil nas áreas de Fonologia, Vocabulário, Fluência e Pragmática. Carapicuiba (SP): Pró-Fono, 2000. 90 p.

BetZ, S. K.; STOEL-GAMMON, C. Measuring articulatory error consistency in children withdevelopmental apraxia of speech. Clin. Ling. Phonetics, v. 19, n. 1, p. 53-66, Jan.-Feb. 2005.

CASTRO, M. M. Estudo da estimulabilidade dos fonemas líquidos laterais e vibrante simples do português brasileiro em crianças normais e com distúrbio fonológico. 2004. 98 f. Dissertação (Mestrado em Semiótica e Lingüística Geral) - Faculdade de Filosofia Letras e Ciências Humanas, Universidade de São Paulo, São Paulo.

CROSBIE, S.; HOLM, A.; DODD, B. Intervention for children with severe speecm disorder: a comparison of two aproaches. Int. J. Lang. Commun. Dis., v. 40, n. 4 , p. 467-491, oct.-dec. 2005.

CUMLEY, G. D. Children with apraxia and the use of augmentative and alternative communication: Introduction. August 2001. Disponível em: <http://apraxiakids.org/slps/cumley.html>. Acesso em: 04 jan. 2002.

DOLLAGHAN, C. A. Evidence-based practice in communication disorders: What do we know, and when do we know it? J. Commun Disord, v. 37, n. 5, p. 391-400, set.-out. 2004.

EDWARDS, M. L. Phonological assessment and treatment in support of phonological processes. Lang. Speech Hear. Serv. Sch., v. 23, n. 3, p. 233-240, jul. 1992.

GALEA, D. E. S. Análise do sistema fonológico em crianças de 2;1 a 3;0 anos de idade. 2003. $99 \mathrm{f}$. Dissertação (Mestrado em Semiótica e Lingüística Geral) - Faculdade de Filosofia Letras e Ciências Humanas Universidade de São Paulo, São Paulo.

GOLDMAN, R.; FRISTOE, M. Goldman-Fristoe tests of articulation. Minnesota: American Guidance Service, 1986.

GOLDSTEIN, B.; FABIANO, L.; IGLESIAS, A. Spontaneous and imitated productions in Spanish-speaking children with phonological disorders. Lang. Speech Hear. Serv. Sch., v. 35, n. 1, p. 5-15, jan. 2004.

HOFFMAN, P. R.; NORRIS, J. A. Phonological assessment as an integral part of language assessment. Am. J. Speech Lang. Pathol., v. 11, n. 3, p. 230-235, ago. 2002.

INGRAM, D. Aspects of Phonological Acquisition. In: INGRAM, D. Phonological Disability in Children. London: Edward Arnold, 1976. cap. 6, p. 10-50.

JONHSON, C. A.; WESTON, A. D.; BAIN, A. B. An objective and Time Efificient Method for Determining Severity of Childhood Speech Delay. Am. J. Speech Lang. Pathol., v. 13, n. 1, p. 55-65, fev. 2004.

KESKE-SOARES, M.; BLANCO, A. P. F.; MOTA, H. B. O desvio fonológico caracterizado por índices de substituição e omissão. R. Bras. Fonoaudiol., v. 9, n. 1, p. 10-18, jan.mar. 2004.

KHAN, L. M. L. The Sixth View: Assessing Preschoolers' Articulation and Phonology from the Trenches. Am. J. Speech Lang. Pathol., v. 11, n. 3, p. 250-254, ago. 2002.
LAW, J.; GARRET, Z.; NYE, C. The efficacy of treatment for children with developmental speech and language delay/ disorder: A meta-analysis. J. Speech Lang. Hear. Res., v. 47, n. 4, p. 924-943, ago. 2004.

LAW, J. The implication of different approaches to evaluating intervention: Evidence from the estudy of language delay/disorder. Folia Phoniatr. Logop., v. 56, n. 4, p. 199-219, jul.-ago. 2004.

PAGAN, L. O.; WERTZNER, H. F. Intervenção no distúrbio fonológico através dos pares mínimos com oposição máxima. Pró-Fono R. Atual. Cient., Barueri, v. 14, n. 3, p. 313-324, set.-dez. 2002.

PAPP, A. C. C. S. Um Estudo sobre a Relação do Aspecto Familial e o Distúrbio Fonológico. 2003. 110 f. Dissertação (Mestrado em Semiótica e Lingüística Geral) - Faculdade de Filosofia Letras e Ciências Humanas, Universidade de São Paulo, São Paulo.

PENÃ-BROOKS, A.; HEDGE, M. N. Development of Articulation and Phonological Skills. In: PENA-BROOKS, A.; HEDGE, M. N. Assessment and Treatment of Articulation and Phonological Disorders in Children. Austin: Pro Ed, 2000. cap. 3, p. 119-174.

PLANTE, E. Evidence based practice in communication sciences and disorders. J. Commun. Disord., v. 37, n. 5, p. 389-390, abr. 2004.

SHRIBERG, L.D.; KWIATKOWSKI, J. Phonological disorders I: A diagnostic classification system. J. Speech Hear. Disord., v. 47, n. 3, p. 226-241, ago. 1982.

SHRIBERG, L. D.; KWIATKOWSKI, J. Continuous Speech Sampling for Phonologic Analysis of SpeechDelayed Children. J. Speech Hear. Disord., v. 50, n. 4, p. 323-334, nov. 1985.

SHRIBERG, L. D. Epidemiologic and diagnostic profiles for five developmental phonological disorders. In: ANNUAL CONVENTION OR THE AMERICAN SPEECH-LANGUE-HEARING ASSOCIATION, 1999, San Francisco. Seminar. San Francisco: 1999. Disponível em: <http://www.waisman.wisc.edu/phonology >. Acesso em: 15 dec. 2002.

SHRIBERG, L. D.; FLIPSEN JR., P.; KARLSSON, H. B.; McSWEENY, J. L. Acoustic phenotypes for speechgenetics studies: An acoustic marker for residual /Z distortions. Clin. Ling. Phonetics, v. 15, n. 8, p. 631-650, dec. 2001.

SHRIBERG, L. D. Classification and misclassification of child speech sound disorders. In: ANNUAL CONVENTION OF THE AMERICAN SPEECHLANGUAGE-HEARING ASSOCIATION, 2002. Paper present at... Atlanta: GA, 2002.

SHRIBERG, L. D; FLIPSEN JR., P.; KWIATKOWSKI, J.; McSWEENY, J. L. A diagnostic marker for speech delay associated with otitis media with effusion: the intelligibility-speech gap. Clin. Ling. Phonetics, v. 17, n. 7, p. 507-528, out.-nov. 2003.

TYLER, A. A.; TOLBERT, L. C.; MICCIO, A. W.; HOFFMAN, P. R.; NORRIS, J. A.; HODSON, B.; SCHERZ, J.; BLEILE, K. Five views of the elephant: Perspectives on the assessment of articulation and phonology in preschoolers. Am. J. Speech Lang. Pathol., v. 11, n. 3, p. 213-214, ago. 2002. 
VIEIRA, M. G.; MOTA, H. B.; KESKE-SOARES, M. Relação entre idade, grau de severidade do desvio fonológico e consciência fonológica. R. Soc. Bras. Fonoaudiol., São Paulo, v. 9, n. 3, p. 144-150, jul.-set. 2004.

WERTZNER, H. F. Fonologia. In: ANDRADE, C. R. F.; BEFI-LOPES, D. M.; FERNANDES, F. D. M.; WERTZNER, H. F. ABFW: Teste de linguagem infantil nas áreas de Fonologia, Vocabulário, Fluência e Pragmática. São Paulo: Pró-Fono, 2000. cap. 1, p. 5-40.

WERTZNER, H. F.; HERRERO, S. F.; PIRES, S. C. F.; IDERIHA, P. N. Classificação do distúrbio fonológico por meio de duas medidas de análise: Porcentagem de consoantes corretas (PCC) e índice de ocorrências dos processos (PDI). Pró-Fono R. Atual. Cient., Barueri, v. 13, n. 1, p. 90-97, mar. 2001.

WERTZNER, H. F.; OLIVEIRA, M. M. F. Semelhanças entre os sujeitos com distúrbio fonológico. Pró-Fono $R$. Atual. Cient., Barueri, v. 14, n. 2, p. 143-152, maio-ago. 2002.

WERTZNER, H. F. O distúrbio fonológico em crianças falantes do português: descrição e medidas de severidade. 2002. 228 f. Tese (Livre-Docência no Departamento de Fisioterapia, Fonoaudiologia e Terapia Ocupacional) Faculdade de Medicina, Universidade de São Paulo, São Paulo.

WERTZNER, H. F.; GALEA, D. E. S. Porcentagem de consoantes corretas-revisadas (PCC-R) e índice de densidade fonológica (PDI) na aquisição fonológica. $R$. Soc. Bras. Fonoaudiol., v. 7, n. 1, p. 44-50, jul. 2002.
WERTZNER, H. F.; ROSAL, C. A. R.; PAGAN, L. O. Ocorrência de otite média e infecções de vias aéreas superiores em crianças com distúrbio fonológico. $R$. Soc. Bras. Fonoaudiol., São Paulo, v. 7, n. 1, p. 31-37, jun. 2002.

WERTZNER, H. F. Distúrbio Fonológico. In: ANDRADE, C. R. F.; MARCONDES, E. (Org.). Fonoaudiologia em Pediatria. 1 ed. São Paulo: Sarvier, 2003. parte I, p.7078.

WERTZNER, H. F. Fonologia: desenvolvimento e alterações. In: FERREIRA, L. P.; BEFI-LOPES, D. M.; LIMONGI, S. C. O. (Org.). Tratado de Fonoaudiologia. 1 ed. São Paulo: Roca, 2004. cap. 62, p. 772-786.

WERTZNER, H. F.; AMARO, L.; TERAMOTO, S. Descritores da classificação da gravidade do distúrbio fonologico. Pró-Fono R. Atual. Cient., Barueri, v. 16, n. 2, p. 139-150, maio-ago. 2004a.

WERTZNER, H. F.; RAMOS, A. C. O.; AMARO, L. Índices fonológicos aplicados ao desenvolvimento fonológico típico e ao transtorno fonológico. R. Soc. Bras. Fonoaudiol., São Paulo, v. 9, n. 4, p. 199-204, out.-dez. 2004b.

WHITEHEAD, R. L.; SCHIAVETTI, N.; MACKENZIE, D. J.; METZ, D. E. Intelligibility of speech produced during simultaneous communication. J. Commun. Disord., v. 37, n. 3, p. 241-253, maio-jun. 2004. 